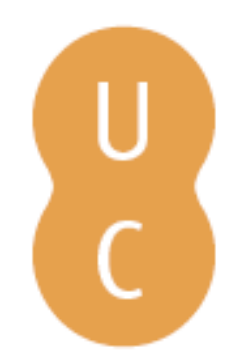

\title{
nommalina
}

\section{Causes of forest fires in Federal Conservation Units of Brazil from 2006 to 2012}

\author{
Autor(es): \\ Costa, Aline das Graças; Torres, Fillipe Tamiozzo Pereira; Lima, \\ Gumercindo Souza; Silva Júnior, Milton Ribas da; Zanuncio, José Cola
}

Publicado por: Imprensa da Universidade de Coimbra

URL

persistente:

URI:http://hdl.handle.net/10316.2/44651

DOI:

DOI:https://doi.org/10.14195/978-989-26-16-506_134

Accessed : $\quad$ 26-Apr-2023 10:57:10

A navegação consulta e descarregamento dos títulos inseridos nas Bibliotecas Digitais UC Digitalis, UC Pombalina e UC Impactum, pressupõem a aceitação plena e sem reservas dos Termos e Condições de Uso destas Bibliotecas Digitais, disponíveis em https://digitalis.uc.pt/pt-pt/termos.

Conforme exposto nos referidos Termos e Condições de Uso, o descarregamento de títulos de acesso restrito requer uma licença válida de autorização devendo o utilizador aceder ao(s) documento(s) a partir de um endereço de IP da instituição detentora da supramencionada licença.

Ao utilizador é apenas permitido o descarregamento para uso pessoal, pelo que o emprego do(s) título(s) descarregado(s) para outro fim, designadamente comercial, carece de autorização do respetivo autor ou editor da obra.

Na medida em que todas as obras da UC Digitalis se encontram protegidas pelo Código do Direito de Autor e Direitos Conexos e demais legislação aplicável, toda a cópia, parcial ou total, deste documento, nos casos em que é legalmente admitida, deverá conter ou fazer-se acompanhar por este aviso.

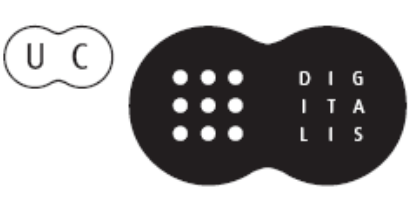




\section{ADVANCES IN}

\section{FOREST FIRE RESEARCH}

\section{8}

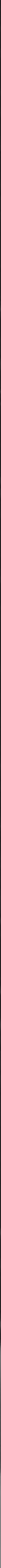


Short contribution - Fire Risk Management

\title{
Causes of forest fires in Federal Conservation Units of Brazil from 2006 to 2012
}

\author{
Aline das Graças Costa*; Fillipe Tamiozzo Pereira Torres; Gumercindo Souza Lima; Milton Ribas da Silva \\ Júnior; José Cola Zanuncio \\ Universidade Federal de Viçosa. Departamento de Engenharia Florestal, Viçosa, Minas Gerais, Brasil, \\ \{alinegrcosta@gmail.com*,fillipe.torres@ufv.br; gslima@ufv.br\}
}

\begin{abstract}
Forest fires represent the greatest threats to biodiversity in Conservation Units (UCs) in Brazil. Knowledge of the causes and regions with the highest occurrences allows the use of fire risk management. The objective of this study was to evaluate the causes of forest fires in the Federal Conservation Units of Brazil from 2006 to 2012 to help in the management of fire risks in Federal UCs of Brazil. The Registros de Ocorrências de Incêndios (ROIs) of the UCs were obtained from the database of the Sistema Nacional de Informações sobre o Fogo (SISFOGO) maintained by the Instituto Brasileiro do Meio Ambiente e dos Recursos Renováveis. The total number of records was 2259 , of which $88.2 \%$ were identified and $11.8 \%$ were unidentified. The unrecorded data evidenced failures in the identification of the fire. Unknown causes accounted for $42.2 \%$ of the records, followed by burn for cleaning (26.7\%) and incendiarys (18.5\%). The "rays" (natural causes) had low representativity (2.8\%). Minas Gerais, Rio de Janeiro, Ceará, Bahia and Piauí were the states with the highest occurrences with 19.8, 15.5, 12, 9.6 and 7.4\%, respectively, of the records for Brazil. UCs suffer burnings for pasture clearance in neighboring areas that reach these protected areas as well as on purposeful fires. The largest fire registry was in Minas Gerais, due to favorable conditions for fire and the prolonged season of drought in this state. Failures in the record of occurrence of fires and in the identification of their causes justify the great number of unknown causes. Fires recorded without identifying the causes and/or registered as unknown causes represent a failure to use the ROI tool by the UC and in the fire identification skill, making it difficult to make decisions against fire. The causes "unknown", "burn for cleaning" and "incendiaries" represent the group of major causes of fires.
\end{abstract}

Keywords: protected areas; fire; fire registry; fire prevention.

\section{Introduction}

Fire is widely used by man to transform and manage the landcapes and is one of the major agents of disturbing of ecosystems (Andreae e Merlet, 2001).

The Conservation Units (UCs) in Brazil are intended for the conservation of biodiversity and fire is a constant threat to threat to UCs (Koproski et al., 2011). The Brazilian UCs are areas with rare and endangered species, with fire-sensitive biomes or small areas and isolated by agricultural monocultures or cities (Medeiros and Fiedler, 2003). The causes of fires should be known for the prevention and reduction of fires (Soares and Santos, 2002).

The main causes of fires are anthropic, such as arsonists and improper use of fire for cleaning neighboring areas and renewal of pastures (Medeiros, 2002). The most common natural causes of fires are electric discharges (lightning) (Matos, 2004).

Brazil has 960 federal UCs of the Sistema Nacional de Unidades de Conservação (SNUC) (MMA, 2017) and knowing the location of the fires allows to determine the areas of greatest risk and to establish specific programs for each region (Soares e Santos, 2002).

The objective of this work was to evaluate the causes of forest fires in the Federal Conservation Units of Brazil from 2006 to 2012 to help in the management of fire risks in Federal Conservation Units of Brazil. 


\section{Methodology}

The data on forest fires in UCs were obtained from the Sistema Nacional de Informações sobre o Fogo (SISFOGO) of the Centro Nacional de Prevenção aos Incêndios Florestais (PREVFOGO), which is maintained by the Instituto Brasileiro do Meio Ambiente e dos Recursos Renováveis (IBAMA, 2015), where the fire occurrence records are located (Registros de Ocorrências de Incêndios - ROIs).

The ROIs provide information about the fire occurrence; terrain; meteorological data; georeferencing; combat data; spending; damages and origin and cause. In the origin and cause is the 26 possible causes and the 33 possible causal agents, being recorded the cause and causal agent corresponding to the fire.

The data were scanned in a Microsoft Excel 2010 worksheet, forming a file with the fires records of the UCs with their respective causes and state of Brazil from 2006 and 2012.

The fire causes were categorized according to the Food and Agriculture Organization (FAO) groups or categories (Santos et al., 2006). FAO does not use the category "unknown" because it considers that it induces the inclusion of other categories of fires in it (Soares, 1988). However, this category was included in this study due to its large record as being a fire cause in the ROIs reports. The causes were grouped into seven categories or groups: unknown (I), several (II), recreational fires (III), incendiary (IV), forest operations (V), burn for cleaning (VI), and rays (VII). The group of "diverse" causes includes the categories of hunting (i), high voltage cable (ii), windborne spark (iii), fireworks (iv), others (v), burn of balloon, (vi) and reignition (vii).

The means comparison of fire causes groups by the period studied considered the groups of causes as treatments and the ocurrence years as repetitions. Causes groupswith low numbers, including zero, were transformed into log values in all fire registers. The means of the treatments were compared by the SNK (Student-Newman-Keuls) test at the 5\% probability in the Excel 2010 program.

The tabulated data allowed the identification of the major fire causes in the Brazilian UCs from 2006 to 2012.

\section{Results and Discussion}

From 2006 to 2012, a total of 2259 fire events were recorded registring $1992(88,2 \%)$ ocurrences with possible cause or causal agent identified. The unrecorded data $(11,8 \%)$ evidenced failures in the identification of the fire cause and/or in the completion of the ROIs (IBAMA, 2006).

The "unknown" cause was the main one of the records in Brazil and, for this reason, was maintained in the same groups. The causes "burn for cleaning" and "incendiary" were the most important, according to Table 1. The largest were from "incendiary", "burn for cleaning" and "unknown" groups.

Table 1 - Causes of forest fires in Federal Conservation Units of Brazil from 2006 to 2012

\begin{tabular}{|c|c|c|c|c|c|c|c|c|c|c|c|c|c|c|c|c|}
\hline & \multicolumn{2}{|c|}{2006} & \multicolumn{2}{|c|}{2007} & \multicolumn{2}{|r|}{2008} & \multicolumn{2}{|r|}{2009} & \multicolumn{2}{|c|}{2010} & \multicolumn{2}{|c|}{2011} & \multicolumn{2}{|c|}{2012} & \multicolumn{2}{|c|}{ Total } \\
\hline & $\mathrm{n}^{\circ}$ & $\%$ & $\mathrm{n}^{\circ}$ & & $\mathrm{n}^{\circ}$ & $\%$ & $\mathrm{n}^{\circ}$ & $\%$ & $n^{\circ}$ & $\%$ & $\mathrm{n}^{\circ}$ & $\%$ & $\mathrm{n}^{\circ}$ & $\%$ & $n^{\circ}$ & $\%$ \\
\hline Unk & 439.0 & 75.0 & 243.0 & 34.9 & 47.0 & 20.0 & 34.0 & 24.1 & 46.0 & 22.5 & 17.0 & 17.9 & 15.0 & 41.7 & 841.0 & 42.2 \\
\hline $\mathrm{BC}$ & 103.0 & 17.6 & 220.0 & 31.6 & 77.0 & 32.8 & 43.0 & 30.5 & 58.0 & 28.4 & 22.0 & 23.2 & 8.0 & 22.2 & 531.0 & 26.7 \\
\hline Incen & 6.0 & 1.0 & 113.0 & 16.2 & 83.0 & 35.3 & 39.0 & 27.7 & 78.0 & 38.2 & 42.0 & 44.2 & 8.0 & 22.2 & 369.0 & 18.5 \\
\hline Div & 10.0 & 1.7 & 74.0 & 10.6 & 14.0 & 6.0 & 10.0 & 7.1 & 15.0 & 7.4 & 11.0 & 11.6 & 1.0 & 2.8 & 135.0 & 6.8 \\
\hline Rays & 19.0 & 3.2 & 18.0 & 2.6 & 6.0 & 2.6 & 10.0 & 7.1 & 1.0 & 0.5 & 0.0 & 0.0 & 1.0 & 2.8 & 55.0 & 2.8 \\
\hline $\mathrm{FO}$ & 3.0 & 0.5 & 15.0 & 2.2 & 3.0 & 1.3 & 4.0 & 2.8 & 3.0 & 1.5 & 1.0 & 1.1 & 3.0 & 8.3 & 32.0 & 1.6 \\
\hline RFi & 5.0 & 0.9 & 13.0 & 1.9 & 5.0 & 2.1 & 1.0 & 0.7 & 3.0 & 1.5 & 2.0 & 2.1 & 0.0 & 0.0 & 29.0 & 1.5 \\
\hline Total & 585 & 100 & 696 & 100 & 235 & 100 & 141 & 100 & 204 & 100 & 95 & 100 & 36 & 100 & 1992 & 100 \\
\hline
\end{tabular}

Causes: unknown (Unk); burn for cleaning (BC); incendiary (Incen); diverse (Div); forestry operations (FO); recreation fires $(\mathrm{RF} i)$ 
The "unknown" cause and data not registered in the ROI are fails in the fire expertise or in the completion of the ROIs, and disagreements of this information make dificult the complete and coherent analysis of the report (IBAMA, 2006; Bontempo, 2011). The lack of regular records of forms in several UCs and/or the sending of incomplete data to PREVFOGO may be due to inadequate structure and staff, or lacking basic information such as burned area, geographic coordinates, fire cause and/or vegetation type (IBAMA, 2006).

The "rays" (natural causes) had low representativity (2.8\%). The "rays" are a uncommon cause of fires in Brazil due to rainfall occurrence increasing the humidity and reducing the amount of fuels available and, consequently, the fire development (Matos, 2004).

The group "smokers" and "railway" were allocated to the "diverse" group because the first group had no records and the second group had a low occurrence $(6.8 \%)$. The group of "diverse" causes is the group of causes with low frequency, of regional character and include causes that do not fit in the other groups (Soares, 1988).

From the 27 Brazilian states, 25 had registered fire cases, including the Federal District, and no occurrences were reported in the states of Acre and Rio Grande do Norte from 2006 to 2012. Minas Gerais (19.8\%) was the state with the highest occurrence of fires, next were Rio de Janeiro (14.5\%), Ceará (12.0\%), Bahia (9.6\%) and Piauí (7.4\%). The others ones had records below $5.9 \%$. The greatest fire risk in Minas Gerais was due to the large commercial forest areas in its territory, and the prolonged dry season (Soares and Santos, 2002).

The "unknown", "burn for cleaning" and "incendiaries" groups were the most important causes of fire (Table 2).

Table 2 - Number of forest fires by groups of causes by SNK test at 5\% probability level

\begin{tabular}{ccccccccccc}
\hline Cause & 2006 & 2007 & 2008 & 2009 & 2010 & 2011 & 2012 & Total & Mean & \\
\hline Unk & 6.08 & 5.49 & 3.85 & 3.53 & 3.83 & 2.83 & 2.71 & 28.32 & 4.05 & $\mathrm{a}$ \\
BC & 4.64 & 5.39 & 4.34 & 3.76 & 4.06 & 3.09 & 2.08 & 27.36 & 3.91 & $\mathrm{a}$ \\
Incen & 1.79 & 4.73 & 4.42 & 3.66 & 4.36 & 3.74 & 2.08 & 24.78 & 3.54 & $\mathrm{a}$ \\
Div & 2.30 & 4.30 & 2.64 & 2.30 & 2.71 & 2.40 & 0.00 & 16.65 & 2.38 & $\mathrm{~b}$ \\
Rays & 2.94 & 2.89 & 1.79 & 2.30 & 0.00 & 0.00 & 0.00 & 9.93 & 1.42 & $\mathrm{~b}$ \\
FO & 1.10 & 2.71 & 1.10 & 1.39 & 1.10 & 0.00 & 1.10 & 8.49 & 1.21 & $\mathrm{~b}$ \\
RFi & 1.61 & 2.57 & 1.61 & 0.00 & 1.10 & 0.69 & 0.00 & 7.58 & 1.08 & $\mathrm{~b}$ \\
\hline
\end{tabular}

Causes: unknown (Unk); burn for cleaning (BC); incendiary (Incen); diverse (Div); forestry operations (FO); recreation fires $(\mathrm{RFi})$

\section{Conclusion}

The "unknown", "burn for cleaning" and "incendiary" causes were the main occurrences of forest fires at federal UCs in Brazil from 2006 to 2012. Minas Gerais was the brazilian State with the highest number of fires. Failures in the identification and recording of fires make it difficult to assess its causes.

\section{Acknowledgements}

To the Coordenação de Aperfeiçoamento de Pessoal de Nível Superior (CAPES) for the availability of the study package and to the Departamento de Engenharia Florestal of the Universidade Federal de Viçosa.

\section{Conflicts of Interest}

The authors declare no conflicts of interest 


\section{References}

Andreae MO, Merlet P (2001) Emission of trace gases and aerosols from biomass burning. Global Biogeochemical Cycles 15, 955-966.

Bontempo GC, Lima GS, Ribeiro GA, Doula SM, Jacovine LAG (2011) Registro de Ocorrência de Incêndio (ROI): evolução, desafios e recomendações. Biodiversidade Brasileira 2, 247-263.

Instituto Brasileiro do Meio Ambiente e dos Recursos Naturais Renováveis (2006): Relatório de ocorrências de incêndios em unidades de conservação federais. Access in: http://ibama.gov.br/phocadownload/ prevfogo/relatorios/incendios_florestais/prevfogo-incendiosflorestais-relatorio_de_incendios_em_ucs_05_08.pdf

Instituto Brasileiro do Meio Ambiente e dos Recursos Naturais Renováveis (2015) Sistema Nacional de Informações Sobre Fogo. Access in: http://siscom.ibama.gov.br/sisfogo/ (acessado em 08 de Março de 2016).

Koproski L, Ferreira MP, Goldammer JG.; Batista, AC (2011) Modelo de zoneamento de risco de incêndios para unidades de conservação brasileiras: o caso do Parque Estadual do Cerrado (PR). Floresta 41, 551-562.

Matos EF (2004) Incêndios Florestais. In: Prevenção e combate aos incêndios florestais em Unidades de Conservação. (Secretaria de Meio Ambiente e Recursos Hídricos do Distrito Federal) pp.19-30.

Medeiros MB (2002) Manejo de Fogo em Unidades de Conservação do Cerrado. In: Boletim do Herbário Ezechias Paulo Heringer 10: 75-88.

Medeiros MB, Fiedler NC (2003) Incêndios florestais no Parque Nacional da Serra da Canastra: desafios para a conservação da biodiversidade. Ciência Florestal 14, 157-168.

Ministério Do Meio Ambiente (2017) Tabela consolidada das Unidades de Conservação. Access in: http://www.mma.gov.br/images/ arquivo/80112/CNUC_Agosto\%20-\%20Categorias_copy.pdf

Santos JF, Soares, RV, Batista AC (2006) Perfil dos incêndios florestais no Brasil em áreas protegidas no período de 1998 a 2002. Floresta 36, 93-100.

Soares RV, Santos JF (2002) Perfil dos incêndios florestais no Brasil de 1994 a 1997. Floresta 32, 219232.

Soares RV (1988) Perfil dos incêndios florestais no Brasil de 1984 a 1987. Floresta. 18, 94-121. 